\title{
Ewolucja marketingu - wymiar historyczny i naukowy
}

\section{Wstęp}

Nie ma pełnej jasności od jakiej daty należy liczyć rozwój marketingu. R. Fullerton uważa, iż początków marketingu doszukiwać się trzeba w rozpoczęciu rewolucji przemysłowej w Wielkiej Brytanii w latach siedemdziesiątych XVIII wieku, a w połowie XIX wieku w Niemczech i ponownie w Wielkiej Brytanii ${ }^{1}$. A. Sagan, opierając się na źródłach R. Bartelsa wskazuje na początek XX wieku jako datę powstania idei i myśli marketingowych ${ }^{2}$. Z kolei, analizując programy akademickie i źródła literaturowe, J. Hagerty pisze, iż przedmiot wykładany na uczelniach z nazwą „marketing” pojawił się w Harvard School of Business Administration w 1909 roku, a w 1915 r. ukazała się książka, która w tytule miała słowo „marketing"3. Można także spotkać się z twierdzeniem, że początków rozwoju marketingu doszukiwać się należy raczej w okresie po drugiej wojnie światowej

Bezsporne jednak pozostaje to, iż marketing ma już kilkudziesięcioletnią historię i wciąż toczy się dyskusja, czym w rzeczywistości on jest. Jego wielowymiarowość, przejawiająca się tym, iż marketing korzysta m.in. z socjo-

${ }^{1}$ R.A. Fullerton, How Modern is Modern Marketing? Marketing's Evolution and the Myth of the "Production Era”, ,Journal of Marketing” 1988, vol. 52.

2 A. Sagan, Teoretyczne podstawy marketingu - 50 lat poszukiwań, „Marketing i Rynek” 2005, nr 7; R. Bartels, Development of Marketing Though - a Brief History, [w:] G. Schwarz, Science in Marketing, J. Wiley \& Sons, New York 1965; R. Bartels, The History of Marketing Thought, Gorsuch Scarisbrick Pub, New York 1988.

${ }^{3}$ Książka nosiła nazwę Marketing Farm Products i napisana została przez L. Welda. J.E. Hagerty, Experiences of an Early Marketing Teacher, „Journal of Marketing” 1936, vol. 1.

${ }^{4}$ F.E. Webster, Marketing Management in Changing Times, „Marketing Management” 2002, January-February; K.G. Celuch, C.J. Kasouf, V. Peruvemba, The Effects of Perceived Market and Learning Orientation on Assessed Organizational Capabilities, „Industrial Marketing Management" 2002, vol. 31; D. Brownlie, M. Saren, The Four Ps of the Marketing Concept: Prescriptive, Polemical, Permanent and Problematical, „European Journal of Marketing” 1991, vol. 26. 
logii ${ }^{5}$, ekonomii i psychologii ${ }^{6}$, a także antropologii, demografii, nauk politycznych czy historii ${ }^{7}$ sprawia, że obszar jego zainteresowania, aktywności, rozwoju wykracza znacznie poza tradycyjnie rozumianą sferę działań marketingowych firmy . Celem artykułu jest identyfikacja naukowych podstaw marketingu i etapów jego ewolucji, a na tym gruncie wskazanie na kierunki jego przyszłego rozwoju.

\section{Naukowe źródła rozwoju marketingu}

Podstawy teoretyczne marketingu mają swoje zakorzenienie w ekonomii ${ }^{9}$. Teoria ekonomii jest fundamentem, na którym powstał marketing, podobnie zresztą jak i nauki o organizacji i zarządzaniu. Najsilniejszy wpływ na rozwój marketingu miały niemiecka szkoła historyczna (G. Schmoller, W. Sombart, M. Weber, B. Hildebrand i inni), szkoła instytucjonalna (T. Veblen, J. Commons, W. Mitchell), austriacka szkoła ekonomii (C. Menger, L. Mises, F. Hayek, M. Rothbard, I. Kirzner, H. Hoppe), ekonomia klasyczna (A. Smith) i neoklasyczna (A. Marshall) oraz oczywiście ogólna teoria ekonomii ${ }^{10}$. Ze względu na fakt, że rozwój marketingu silnie związany jest z rynkiem amerykańskim, uważa się, że szczególnie ta pierwsza, niemiecka szkołą historyczna, wywarła silny wpływ na rozwój myśli marketingowej w początkowym okresie ${ }^{11}$.

Historyczna szkoła w ekonomii rozwinęła się w połowie XIX wieku w Niemczech. Była ona reakcją na rozczarowanie teorią ekonomii klasycznej. Twórcy

${ }^{5}$ C.T. Jonassen, Contributions of Sociology to Marketing, ,Journal of Marketing” 1959, October.

${ }^{6}$ R. Bartels, The History...

7 R. Bartels et al., A Statement of Marketing Philosophy, „Journal of Marketing” 1965, vol. 29.

${ }^{8}$ R. Bartels, The Identity Crisis in Marketing, „Journal of Marketing” 1974, October; T. Ambler, F. Kokkinaki, S. Puntoni, D. Riley, Assessing Market Performance - The Current State of Metrics, Centre for Marketing, London Business School, Working Paper 2001, September.

${ }^{9}$ Przekonanie takie jest powszechne i niekwestionowane - por. K. Białecki, T. Gołębiowski, W poszukiwaniu tożsamości marketingu - marketing a ekonomia i zarządzanie, [w:] Kontrowersje wokół marketingu w Polsce-tożsamość, etyka, przyszłość, red. L. Garbarski, Wydawnictwo Wyższej Szkoły Przedsiębiorczości i Zarządzania im. Leona Koźmińskiego w Warszawie, Warszawa 2004 oraz L. Żabiński, O niektórych argumentach krytyki marketingu jako dyscypliny nauki-polemicznie, ibidem.

${ }^{10}$ R. Bartels, The Identity...; W. Alderson, R. Cox, Towards a Theory of Marketing, ,Journal of Marketing" 1948, vol. XIII.

${ }^{11}$ USA jest kolebką światowego marketingu. Większość amerykańskich teoretyków marketingu, która była jego prekursorami, zdobywała wykształcenie w Niemczech pod koniec XIX w. i na początku wieku XX, gdy dominowała tam historyczna szkoła w ekonomii - Ch. Howell, Toward a History of Management Thought, „Business and Economic History” 1995, vol. 21; D.G.B. Jones, D.D. Monieson, Early Development of the Philosophy of Marketing Thought, ,Journal of Marketing" 1990, vol. 54. 
szkoły historycznej wyrażali swoje niezadowolenie z ograniczonych możliwości wyjaśnienia przez klasyczną ekonomię problemów, jakie uwidoczniły się w Niemczech w tym okresie, a związanych z dynamicznym wzrostem tej gospodarki. Podstawy metodologiczne wspomnianej szkoły wiążą się z W. Roscherem, który podważał ideę uniwersalnego systemu teoretycznego, argumentując, że prawa i zachowania ekonomiczne są ograniczane przez historyczny, społeczny $\mathrm{i}$ instytucjonalny kontekst ${ }^{12}$. Z tego powodu prawa ekonomii mają wymiar interdyscyplinarny i winny być oparte na spojrzeniu historycznym, społecznym i ekonomicznym. W konsekwencji twórcy historycznej szkoły w ekonomii negowali zasady ekonomii jako nauki teoretycznej i odrzucali zasady liberalizmu gospodarczego, który udowadniał możliwości zachowania równowagi gospodarczej jedynie według działań praw ekonomicznych. W zamian proponowali protekcjonizm i interwencjonizm państwa. Dalszy rozwój tej szkoły poprzez rozwijanie takich zagadnień, jak warunki pracy, system ubezpieczeń i świadczenia emerytalne dał początek państwu opiekuńczemu. Twórcy szkoły historycznej, co znalazło swoje odniesienie również w późniejszym rozwoju marketingu, przede wszystkim amerykańskiego, opierali się głównie na analizie historycznej, metodach statystycznych, pragmatyzmie, stosowali metody indukcyjne, odrzucając dedukcję jako metodę badań ${ }^{13}$.

Szkoła instytucjonalna została rozwinięta w Stanach Zjednoczonych w drugiej połowie lat osiemdziesiątych XIX wieku. Była silnie związana ze szkołą historyczną. T. Veblen, J. Commons, W. Mitchell, jako główni przedstawiciele tej szkoły, podkreślali znaczenie czynników historycznych, społecznych i instytucjonalnych w tworzeniu praw ekonomicznych. Wskazywali oni na zmienność, niestałość otoczenia. Argumentowali, że czynniki otoczenia wpływają w sposób bezpośredni na jednostkę bądź pośrednio poprzez instytucje czy system społeczny. Rynek traktowany jest więc jako suma interakcji zachodzących pomiędzy różnymi jego podmiotami. Założenia intelektualne szkoły instytucjonalnej zwróciły więc uwagę m.in. na zachowania grupowe i ich rolę w marketingu, J. Commons wprowadził podział, wykorzystywany potem w teorii zachowania nabywcy, na transakcje rutynowe i w pełni negocjowane ${ }^{14}$.

Szkoła austriacka, określana wiedeńską, ma swoje początki w latach siedemdziesiątych XIX wieku. Odrzuca ona metody badań stosowane w naukach przyrodniczych, na korzyść odkrywania celowego działania człowieka (prakseologia). Przedstawiciele tej szkoły odrzucają na przykład obserwację jako metodę badań,

\footnotetext{
12 http://cepa.newschool.edu/het/schools/historic.htm.

13 A. Sagan, op. cit.; D.G.B. Jones, D.D. Monieson, op. cit.

14 W. Anderson, R. Cox, Towards a Theory of Marketing, ,Journal of Marketing” 1948, vol. XIII.
} 
ze względu na to, że w przeciwieństwie do nauk przyrodniczych, gdzie badanie odbywa się w laboratorium i różne czynniki mogą być kontrolowane, zachowanie ludzkie jest zbyt złożone, aby tego typu metoda była możliwa do zastosowania. Twórcy tej szkoły dostrzegali w przedsiębiorczości siłę sprawczą rozwoju gospodarczego, a własność prywatną traktowali jako kluczową dla skutecznego wykorzystania zasobów. Podkreślali także znaczenie niepewności w podejmowaniu decyzji rynkowych i rozumieli, że każda decyzja gospodarcza obciążona jest ryzykiem, gdyż podejmowana jest na podstawie niepełnych informacji.

Oczywiście cała lista wielu znakomitych ekonomistów przyczyniała się przez lata do rozwoju marketingu. Koncepcja elastyczności popytu A. Marshalla, teoria wartości A. Smitha, niedoskonałej konkurencji E. Chamberlina, konkurencji monopolistycznej J. Robinson, idea kosztów stałych zapoczątkowana m.in. przez J. Clarka to tylko niektóre przykłady istotnych myśli, na których wielu autorów opracowań ze sfery marketingu opierało swoje prace, próbując opisać i wyjaśnić mechanizmy rządzące działaniami rynkowymi ${ }^{15}$. Należy jednak na tym etapie przedstawić dwa wnioski. Po pierwsze, tak zróżnicowane myśli ekonomiczne, z jakich korzysta marketing, budzą zastanowienie pod kątem spójności i jednolitości podstaw teoretycznych tej sfery wiedzy. Po drugie, w sposób wyrazisty, szczególnie na gruncie teorii instytucjonalnej, można dostrzec także silne związki marketingu z naukami społecznymi, głównie z socjologią, antropologią oraz psychologią. Wydaje się, że obok ekonomii to druga istotna gałąź wiedzy, która wywarła wpływ na marketing w fazie jego tworzenia i rozwoju. Demografia, teoria motywacji, zachowania grupowe, skalowanie, przemiany społeczne czy kultura to tylko niektóre obszary socjologii, z których od lat korzysta marketing ${ }^{16}$. Nie wchodząc $\mathrm{w}$ dalsze rozważania historyczno-literaturowe warto podsumować, że od strony fundamentów teoretycznych marketing oparł swoje powstanie i rozwój głównie na ekonomii i naukach społecznych. Zróżnicowane teorie zarówno pod kątem dziedzin nauki, jak i nurtów teoretyczno-badawczych, z jakich wywodzi się marketing potwierdzają tezę o wielowymiarowości i niejednorodności jego źródeł jako nauki, dziedziny wiedzy i praktyki działania. Znajomość praw ekonomii, zasad zachowania jednostek i czynników wpływających na to zachowanie wraz z umiejętnością wnioskowania indukcyjnego opartego na metodach statystycznych są ramami teoretycznymi marketingu.

${ }_{15}$ R. Bartels, The Identity...

16 R. Bartels, Sociologists and Marketologists, „Journal of Marketing” 1959, vol. 24. 


\section{Etapy ewolucji marketingu}

Kolebką współczesnego marketingu są Stany Zjednoczone Ameryki Północnej. Formalny rozwój marketingu związany jest z rozwojem nauk o zarządzaniu. Rozpoczął się on z początkiem XX wieku. Największy wpływ na początki rozwoju marketingu mieli dwaj uczeni amerykańscy - Edwin Francis Gay, pierwszy dziekan Harvard Business School na Uniwersytecie Harvarda ${ }^{17}$ oraz Richard T. Ely, pierwszy dyrektor SzkołyEkonomii na Uniwersytecie Wisconsin ${ }^{18}$. Zarówno E. Gay, jak R. Ely wraz z grupą wielu innych amerykańskich ekonomistów swoje szlify akademickie zdobywali w Niemczech, pozostając pod silnym wpływem myśli historycznej szkoły ekonomii.

Pierwsze programy, w których poruszano problematykę marketingu, a później przekształcone zostały w kursy z zakresu marketingu dotyczyły z jednej strony problematyki wymiany, z drugiej dystrybucji ${ }^{19}$. I tak np., jak podaje J. Hagerty, na Uniwersytecie Illinois już w 1902 roku oferowane były programy: handel wewnętrzny i polityka handlowa, handel zagraniczny i polityka handlowa, polityka a rynek wewnętrzny i zagraniczny. Na Uniwersytecie w Nowym Jorku prowadzony był w tym samym czasie program praktyka i organizacje biznesowe, surowce, organizacje przemysłowe i zarządzanie. W 1909 roku pojawił się na Uniwersytecie w Pittsburghu, jak można przypuszczać jako pierwszy z nazwą ,,marketing”, program marketing produktów, a prowadzony na Harvard School program organizacja handlowa i metody przekształcił się w roku $1914 \mathrm{w}$ program marketing. Kursy te zapoczątkowały szybki rozwój programów, które już nie tylko dotyczyły problematyki marketingu, ale także miały to słowo w nazwie.

W początkowym okresie rozwoju marketingu w sferze akademickiej, publikacje poruszające zagadnienia z marketingu dotyczyły głównie, jak już zauważono, problematyki rolnej oraz dystrybucji. Jako początki literatury marketingowej traktuje się publikacje E. Adamsa - Modern Farmer (1899), J.O.H.N. Higgenbottoma - Merchandising and Credit (1902), Ch.E. Russella - The Greates Trust in the Word (1905) oraz publikację S. Spalinga - Introduction to Business Organization (1906), w której autor, w części Organization of Distributive Industries porusza zagadnienia związane z rozwojem rynków, wymianą,

${ }_{17}$ R. Bartels, The Development of Marketing Thought, Homewood, Irwin Press, Chicago IL, 1962, s. 34.

${ }_{18}$ D.G. Jones, D.D. Monieson, op. cit.

${ }^{19}$ Choć na przykład pierwsze programy z zakresu reklamy oferowane były już w 1896 r. przez Uniwersytet Minnesota czy Northwestern University w Evanston. Por. P.D. Converse, The Development of the Science of Marketing - An Exploratory Survey, „Journal of Marketing” 1945, vol. 10. 
bezpośrednią sprzedażą, handlem hurtowym i detalicznym, zamówieniami pocztowymi, reklamą itp.

Właściwie jednak dopiero w latach 1913-1915 pojawiły się pozycje książkowe, które stworzyły podwaliny teoretyczne pod programy z zakresu marketingu. Były to książki P. Cheringtona Adveritising as a Business Force (1913), L. Welda Marketing of Farm Product (1915) oraz A. Shawa An Approach to Business Problems $(1916)^{20}$. Co ciekawe, już wtedy pojawiały się głosy krytyczne wobec marketingu, a co jeszcze bardziej interesujące dotyczyły one podobnych zarzutów, jakie stawiane są dzisiejszemu marketingowi. Na przykład w latach 1911-1914 E.D. Jones opublikował serię artykułów, w których w części wstępnej zatytułowanej The Larger Aspects of Private Business wskazywał na nieskuteczność marketingu przejawiającą się m.in. tym, że np. w handlu detalicznym koszty marketingu stanowią ok. 50\% ceny produktów, z czego zdecydowana większość jest marnotrawiona na reklamę oraz przepych w sklepach detalicznych ${ }^{21}$.

Analizując dostępne informacje, opublikowane materiały i wprowadzane zmiany, a w szczególności opierając się na publikacjach R. Bartelsa ${ }^{22}$, W. Wilkiego i E. Moore ${ }^{23}$ oraz S. Vargo i R. Luscha ${ }^{24}$ można podzielić cały okres rozwoju teorii marketingu na pięć części. Oczywiście podane lata są datami umownymi, gdyż proces przechodzenia od jednego okresu do drugiego odbywał w sposób płynny:

1. Powstania i formowania (do $1920 \mathrm{roku}$ ).

2. Okres wczesnego rozwoju (1920-1950).

3. Okres dynamicznego rozwoju i redefinicji (1950-1980).

4. Okres stabilizacji (1980-1990).

5. Okres zharmonizowanego rozwoju (1990-obecnie).

Graficznie można przedstawić to jak na rys. 1.

Pierwszy okres ,powstania i formowania” rozpoczyna się wraz z wymianą dóbr, powstaniem rynku i rozwojem teorii wartości ${ }^{25}$. Praktyka marketingu łączona jest z rewolucją przemysłową i okresem połowy XVIII wieku w Anglii i Niemczech oraz latami trzydziestymi XIX wieku w USA. Marketing rozwija się jako dziedzina akademicka opierając się na naukach, które mają już określone

${ }^{20}$ D.G. Jones, D.D. Monieson, op. cit.; J.E. Hagerty, op. cit.

${ }^{21}$ E.D. Jones, The Larger Aspects of Private Business, „Mill Supplies” 1911, vol. 1.

${ }^{22}$ R. Bartels, The Development...

${ }^{23}$ W.L. Wilkie, E.S. Moore, op. cit.

${ }^{24}$ S.L. Vargo, R.F. Lusch, Evolving to a New Dominant Logic for Marketing, ,Journal of Marketing" 2004, vol. 68.

${ }_{25}$ A. Shaw, Some Problems in Market Distribution, „Quarterly Journal of Economics” 1912 , vol. 12; A. Marshall, Principles of Economics (1890), Reprint, Macmillan, London 1927; J. Say, A Treatise on the Political Economy, Wells and Lilly, Boston 1821; A. Smith, A Inquiry into the Nature and Causes of the Wealth of Nations (1776), Reprint, W. Strahan and T. Cadell, London 1904. 


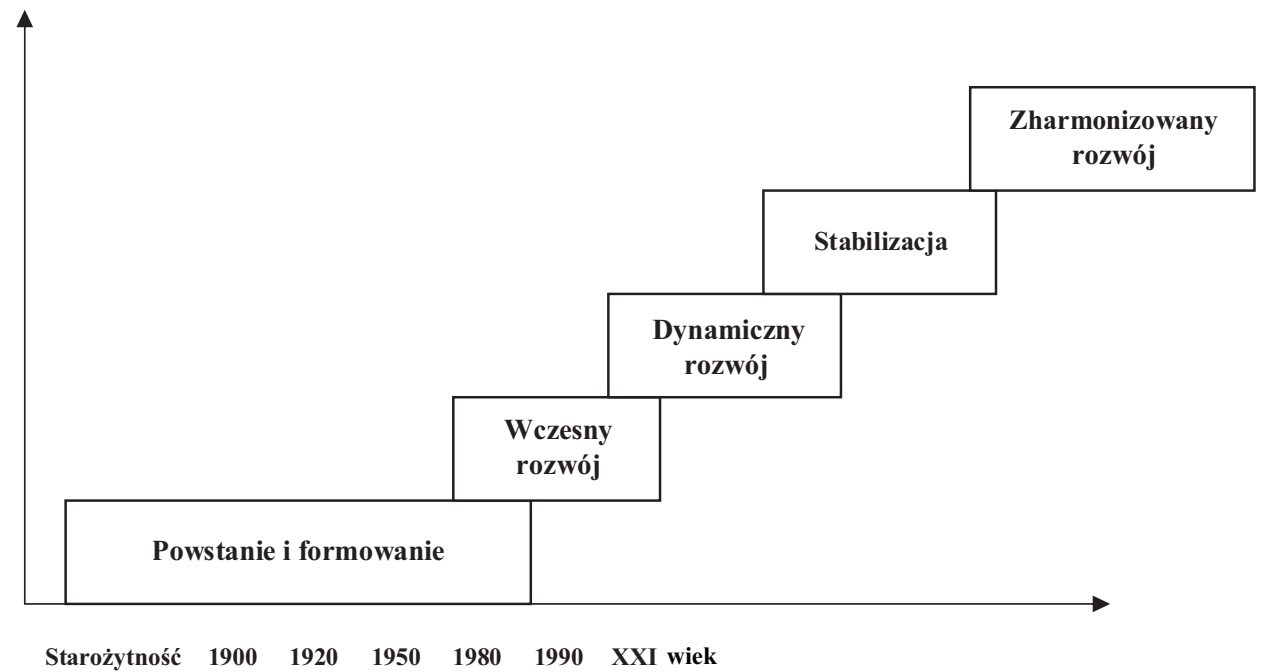

Rysunek 1. Etapy rozwoju marketingu

Źródło: opracowanie własne.

osiągnięcia - ekonomii, socjologii, a także psychologii i antropologii. Podkreślić należy silny wpływ poglądów społecznych i szkoły historycznej w ekonomii na rozwój marketingu. Nauka marketingu koncentrowała się wtedy na analizie funkcjonowania rynku i jego uczestników - konsumentów i rządu ${ }^{26}$. Początkowy rozwój związany jest głównie z rynkami rolnymi i problematyką dystrybucji, w mniejszym stopniu reklamy i handlu. Podkreślić należy również, że ówczesna ekonomia koncentrowała się na czynnikach produkcji (ziemia, siła robocza, kapitał) jako na nośnikach wartości i nie bardzo wiedziano, jak traktować usługi, takie jak dystrybucja. W tym okresie pojawily się pierwsze zwarte publikacje poświęcone problematyce już nie tylko handlu czy dystrybucji, ale marketingu, które stanowiły początki podstaw teoretycznych marketingu i odróżnienia go od innych dziedzin wiedzy ${ }^{27}$. W tym okresie pojawiły się m.in. opracowania, które stanowiły później podstawy teoretyczne rozwoju szkoły instytucjonalnej ${ }^{28}$, funk-

26 W.L. Wilkie, E.S. Moore, op. cit.

27 D. Bussiere, Evidence of a Marketing Periodic Literature Within the American Economic Association, 1895-1936, „Journal of Macromarketing” 2000, vol. 20; R. Savitt, Pre-Aldersonian Antecedents to Macromarketing - Insights from the Textual Literature, „Journal of the Academy of Marketing Science" 1990, vol. 18.

28 Szkoła instytucjonalna poruszała problem marketingu jako obszaru aktywności określonych instytucji - hurtownika, brokera. P. Nystrom, The Economics of Retailing, vol. 1/2, Ronald Press, New York 1915. 
cjonalnej ${ }^{29} \mathrm{i}$ commodities - produktowej ${ }^{30}$. Okres ten był więc okresem narodzin marketingu jako przedmiotu nauczania na uniwersytetach, jako tematu publikacji i jako przedmiotu nazwanej aktywności instytucji rynku. To okres formowania się myśli i założeń teoretycznych.

Lata 1920-1950 to wczesny okres rozwoju. W początkowej fazie tego okresu, jak podaje R. Bartels, pojawiły się opracowania, które podejmowały próbę określenia zasad i fundamentów tej sfery funkcjonowania rynku i przedsiębiorstw oraz integracji dotychczasowych myśli w jeden spójny sposób ${ }^{31}$. Główny nacisk kładziono na transakcję i jej efekty oraz odpowiedź na pytania jak organizacje realizują funkcje marketingowe i w jakim stopniu dodają one wartości produktom. Jak uważano, głównymi wartościami dodawanymi do produktów przez marketing była użyteczność miejsca i czasu, a więc korzyści związane z dystrybucją, która stanowiła jeden z głównych strumieni teoretycznych i praktycznych powstania marketingu. Poza samą kwestią korzyści miejsca i czasu, nacisk kładziony był także na posiadanie i własnośćc ${ }^{32}$. Na przykład F. Clark definiował wtedy marketing jako wysiłki zmierzające do transferu własności dóbr ${ }^{33}$. Okres ten kończy się coraz powszechniej stawianym pytaniem o przyszłość marketingu i jego naukowy status $^{34}$. Na przykład W. Alderson i R. Cox kończą swój artykuł Towards a Theory of Marketing stwierdzeniem, że teoria marketingu nie dostarczy nam zrozumienia jego istoty, jeśli będzie ignorować interakcje zachodzące pomiędzy systemem i procesem. Wyrażają oni dalej także wątpliwość, czy ekonomia będzie w stanie pomóc $\mathrm{w}$ opisaniu tych zależności ${ }^{35}$.

Okres wczesnego rozwoju marketingu to także czas budowania profesjonalnej infrastruktury marketingowej (stowarzyszenia profesjonalne, konferencje, czasopisma itp. $)^{36}$. W 1924 roku powstała National Association of Teachers of Marketing and Advertising, a w 1930 - American Marketing Society, które re-

${ }^{29}$ Szkoła funkcjonalna zajmuje się funkcjami, jakie wykonuje marketer i ich celami P.T. Cherington, The Elements of Marketing, Macmillan, New York 1920.

${ }^{30}$ Szkoła produktowa (commodities) koncentrowała swoją uwagę na działaniach marketingowych realizowanych w odniesieniu do określonych produktów czy ich kategorii oraz cechach tych produktów - M.T. Copeland, Marketing Problems, A.W. Shaw, New York 1923.

31 Jak podaje Bartels (R. Bartels, The Development...) należą do nich m.in., F.E. Clark, Principles of Marketing; Macmillan, New York 1922; H.H. Maynard, W.C. Weidler, T.N. Beckman, Principles of Marketing, Ronald Press Company, New York 1927; P.D. Converse, The Elements of Marketing, Prentice Hall, New York 1935.

32 S.L. Vargo, R.F. Lusch, The Development...

${ }^{33}$ Na podstawie R. Bartles, The Development...

34 P.D. Converse, op. cit.; W. Alderson, R. Cox, op. cit.; R. Bartels; Can Marketing Be a Science?, „Journal of Marketing” 1951, vol. 15.

${ }^{35}$ W. Alderson, R. Cox, op. cit.

${ }^{36}$ W.L. Wilkie, E.S. Moore, op. cit. 
prezentowały interes marketerów. Organizacja ta w 1934 roku zaczęła wydawać „American Marketing Journal”, który w roku 1935 zmienił nazwę na „National Marketing Review". W latach 1936-1937 obie organizacje (National Association of Teachers of Marketing and Advertising oraz American Marketing Society) połączyły się pod wspólna nazwą American Marketing Association i zmieniły nazwę wydawanego czasopisma na znany obecnie „Journal of Marketing”37. W 1925 roku zaczął się ukazywać w Nowym Jorku „Journal of Retailing”.

Podsumowując można stwierdzić, że okres ten, jak uważają W. Wilkie i E. Moore, to lata znacznie większej koncentracji na opisie operacji marketingowych niż na rozwiązywaniu problemów zarządczych. Zwrócono także uwagę na czynniki zewnętrzne oraz stawiano pytanie o wpływ marketingu na społeczeństwo przy uwzględnieniu czynników ekonomicznych, społecznych i politycznych. Aspekt społeczny znajdował także wyraz w zarzutach stawianych w tym okresie marketingowi, a dotyczących kosztów dystrybucji, wartości reklamy i polityki cenowej. Jak uważają autorzy, opierając się m.in. na publikacjach W. Aldersona, ówcześni akademicy i praktycy marketingu postrzegali znacznie szerzej rolę, jaką winien odgrywać marketing niż dzieje się to $\mathrm{w}$ obecnych czasach ${ }^{38}$. Pojawienie się takich tendencji, w końcu lat czterdziestych XX wieku przyczyniło się do ożywionej dyskusji nad statusem marketingu i szybkiego jego rozwoju, głównie jako funkcji zarządczej, w latach 1950-1980.

Zapoczątkowany pod koniec okresu wczesnego rozwoju marketingu trend zmierzający w kierunku, po pierwsze, redefiniowania roli marketingu, po drugie położenia większego nacisku na jego stronę zarządczą uległ przyśpieszeniu w okresie powojennym. Dotyczyło to dyskusji nad naukowymi fundamentami marketingu, a także nad rozważaniami odnoszącymi się do roli marketera i sposobami podejmowania przez niego decyzji. Okres powojenny przyniósł wzrost rynku i rozwój tzw. mass-marketingu, spowodowanych ograniczeniami w konsumpcji w czasie wojny, okresem tzw. baby-boom, rozwojem technologii, nowych form dystrybucji i innych. Marketerzy napotykali więc nowe możliwości działania, a dziedzina marketingu i grono marketerów dynamicznie się powiększało. W efekcie koncepcja marketingu zaczęła obejmować bardziej marketera, jego decyzje i sposób postępowania. Jak podają W. Wilkie i E. Moore ${ }^{39}$, za D. Jones i E. Shaw ${ }^{40}$, najważniejszymi publikacjami w tym czasie dotyczącymi zarządczej

${ }^{37}$ Ibidem; R.A. Kerin, In Pursuit of an Ideal - The Editorial and Literary History of the Journal of Marketing, ,Journal of Marketing” 1996, vol. 60.

${ }_{38}$ W. Alderson, A Marketing View of Competition, ,Journal of Marketing” 1937, vol. 1.

${ }^{39}$ W.L. Wilkie, E.S. Moore, op. cit.

${ }^{40}$ D.G.B. Jones, E.H. Shaw, A History of Marketing Thought, [w:] B.A. Weitz, R. Wensley, Handbook of Marketing, Sage Publications, Thousand Oaks 2002. 
sfery marketingu były: W. Aldersona Marketing Behavior and Executive Action ${ }^{41}$, J. Howarda Marketing Management - Analysis and Planning ${ }^{42}$ oraz E. McCarthy'ego Basic Marketing - A Managerial Approach ${ }^{43}$. Oczywiście w drugiej połowie tego okresu głównym autorem nurtu, który scementował początkowe idee związane z nurtem zarządczym był $\mathrm{Ph}$. Kotler ${ }^{44}$. Należy podkreślić, że kolejne publikacje Ph. Kotlera do dziś wpływają na rozumienie i postrzeganie działań marketingowych zarówno przez akademików, jak i praktyków marketingu.

Nakierowanie na proces podejmowania decyzji i postrzeganie marketingu bardziej jako aktywności menedżerskiej wyraźnie pociągnęło za sobą potrzebę zaadaptowania osiągnięć nauk ścisłych, w szczególności matematyki i statystyki, do zakresu nauk o marketingu. Skutkowało to z jednej strony rosnącym wykorzystywaniem naukowych metod badawczych, $\mathrm{z}$ drugiej coraz powszechniejszym wykorzystywaniem metod analitycznych przez praktyków. Poza powyższymi wskazać należy jeszcze na jeden ważny element ówczesnej myśli marketingowej. Już nie funkcje i operacje marketingowe czy konsekwencje tych działań dla społeczeństwa, ale klient znalazł się w centrum zainteresowania firm. W efekcie uznano otwarcie, że wartość wyznaczana jest na rynku, a nie w firmie ${ }^{45}$. Wskazać również trzeba, że umiejscowienie klienta w centrum zainteresowania skupiło uwagę akademików na kliencie, zachowaniu klienta, czynnikach wpływającymi na jego wybory. Jak podają W. Wilkie i E. Moore ważniejsze koncepcje, modele czy techniki, jakie pojawiły się w tym okresie, były związane właśnie z tymi nurtami. Były to m.in. - koncepcja marketing-mix, cykl życia produktów, proces rozwoju nowego produktu, system informacji marketingowej, metoda DAGMAR, strategie segmentacji, audyt marketingowy, pozycjonowanie i mapy percepcji i inne. Ponadto metody zapożyczane z innych nauk, głównie matematyki, statystyki, psychologii znalazły szerokie zastosowanie w marketingu. Dotyczy to w szczególności teorii postaw, motywacji, stylów życia, prognozowania, analizy trade-off, analizy odchyleń, skalowania wielowymiarowego, analizy Bayesa i innych ${ }^{46}$.

${ }^{41}$ W. Alderson, Marketing Behavior and Executive Action, Richard D. Irwin, Homewood 1957.

42 J.A. Howard, Marketing Management - Analysis and Planning, Richard D. Irwin, Homewood 1957.

${ }^{43}$ E.J. McCarthy, Basic Marketing - A Managerial Approach, Richard D. Irwin, Homewood 1960.

${ }^{44} \mathrm{Ph}$. Kotler, Marketing Management - Analysis, Planning and Control, Prentice Hall, Englewood Cliffs, NJ, 1967.

45 P.F. Drucker, The Practice of Management, Hopper and Row, New York 1954; J.B. McKitterick, What is Marketing Management Concept, [w:] F.M. Bass, Frontiers of Marketing Thought and Science, American Marketing Association, Chicago 1957; T. Levitt, Marketing Myopia, „Harvard Business Review" 1960, vol. 38.

46 J.G. Myers, W.F. Massy, S.A. Greyser, Marketing Research and Knowledge Development, Prentice Hall, Englewood Cliffs, NJ 1980. 
Dynamiczny rozwój marketingu w tym okresie wiązał się także z szybkim poszerzaniem infrastruktury marketingowej - liczbą członków stowarzyszeń, liczbą publikowanych artykułów w czasopismach marketingowych, liczbą absolwentów studiów marketingowych oraz nadawanych stopni doktora z zakresu zarządzania. I tak np. na początku lat pięćdziesiątych American Marketing Association liczyła niespełna 4000 członków, to pod koniec tego okresu liczba ich wzrosła ponad czterokrotnie. Liczba opublikowanych łącznie artykułów z zakresu marketingu w USA w 5 głównych czasopismach ${ }^{47}$ do 1950 r. wynosiła ponad 1400, gdy pod koniec 1980 roku osiągnęła poziom prawie 6000 artykułów $^{48}$. W tym też okresie powołano do życia Marketing Science Institute, który w ciągu pierwszych 10 lat istnienia rozszerzył liczbę swoich członków do $1000 \mathrm{w} 20$ krajach świata $^{49}$ i do dzisiaj pozostaje kluczową instytucją naukowo-badawczą na świecie.

Końcową część lat siedemdziesiątych i lata osiemdziesiąte nazwano okresem stabilizacji. Mimo że pojawiły się nowe koncepcje w sferze marketingu nie przybliżyły one ani marketingu do naukowego statusu, ani nie rozwinęły w radykalny sposób praktycznej sfery działań marketingowych, może z wyjątkiem marketingu partnerskiego ${ }^{50}$, który był w dużym stopniu związany z rozwojem sektora usług i wzrostem jego znaczenia. Okres ten charakteryzuje się z jednej strony silnym naciskiem na społeczny aspekt działań marketingowych, z drugiej strony zaś następuje fragmentaryzacja działań marketingowych ${ }^{51}$, koncentracja na wybranych metodach, bez szerszego kontekstu. Wzrost znaczenia tzw. marketingu społecznego związany był, o czym wspomniano, z rozwojem sektora usług i potrzebą oparcia działań firmy na budowaniu bezpośrednich relacji z klientem. W efekcie aspekty społeczne, elementy emocji zaczynają odgrywać dużą rolę.

W okresie tym, jak zauważa R. Bartels, pojawiają się także pojęcia społecznej orientacji marketingowej czy odpowiedzialności społecznej organizacji ${ }^{52}$. Rozwinięta w tym czasie koncepcja makromarketingu, jak celnie zauważa A. Sagan, niosła skutki uboczne, wyrażane w zatracaniu tożsamości marketingowej

47 „Journal of Retailing” (ukazuje się od 1925), „Journal of Marketing” (1936), „Journal of Advertising Research” (1960), „Journal of Marketing Research” (1964), „Journal of Consumer Research" (1974).

${ }^{48}$ W.L. Wilkie, E.S. Moore, op. cit.

49 Ibidem.

${ }^{50}$ Np. L.L. Berry, Relationship Marketing, [w:] L.L. Berry, L. Schostack, G.D. Upah, Emerging Perspectives of Services Marketing, American Marketing Association, Chicago 1983; E. Gummesson, The New Marketing - Developing Long-Term Interactive Relationships, „Long Range Planning" 1987, vol. 20/4.

${ }^{51}$ W.L. Wilkie, E.S. Moore, op. cit.

${ }^{52}$ R. Bartels, The Development... 
i niejasności jego definiowania ${ }^{53}$. Okres ten przyniósł jednak dwie ważne korzyści. Po pierwsze wskazał i zapoczątkował erę rozwoju marketingu usług, marketingu relacji, który dzisiaj ewoluuje w kierunku szerszego zastosowania technologii i wykorzystania tej wiedzy w zakresie funkcjonowania firm w świecie Internetu. Osiągnięcia takich autorów, jak Ch. Gronroos, V. Zeithaml, A. Parasuraman, L. Berry pozwalają lepiej zrozumieć zachowanie klientów w gospodarce opartej na usługach, gospodarce wiedzy ${ }^{54}$. Po drugie okres stabilizacji lat osiemdziesiątych dał wyraźny impuls do poszukiwania od nowa tożsamości i źródeł marketingu w początkach lat dziewięćdziesiątych. Od strony infrastruktury pojawiło się w latach osiemdziesiątych wiele nowych czasopism dotykających sfery marketingu, ale miały one, podobnie jak nauka, tendencje do wąskiej specjalizacji. Na przykład pojawiły się takie czasopisma, jak „Journal of Personal Selling \& Sales Management” (1980), „Journal of Consumer Marketing” (1983), „Journal of Product Innovation and Management” (1984), „Journal of Interactive Marketing" $(1987)^{55}$.

Obecnie trwający okres rozpoczął się od kontynuacji rozważań dotyczących przyszłości marketingu i jego roli. Obficie cytowane artykuły Marketing on the Crossroads oraz Marketing's Mid-life Crisis wyraźnie podważały obecne działania marketingowe i wskazywały na potrzebę redefinicji jego pojęcia ${ }^{56}$. Dla tego okresu charakterystyczne, w przekonaniu autora, są trzy główne nurty. Po pierwsze szeroko zakrojone poszukiwania tożsamości, możliwości określenia i co więcej zbadania zorientowania rynkowego organizacji. Badania zmierzają do określenia intelektualnych fundamentów marketingu i wskazania na jego miejsce i zadania w organizacji. Nurt ten, zapoczątkowany przez takich autorów, jak B. Shapiro ${ }^{57}$, A. Kohli i B. Jaworski ${ }^{58}$ oraz J. Narver i S. Slater ${ }^{59}$, później kon-

${ }^{53}$ A. Sagan, op. cit.

${ }^{54}$ M.in.: Ch. Gronroos, A Service Quality Model and its Marketing Implications, „European Journal of Marketing" 1984, vol. 18; V.A. Zeithaml, A. Parasuraman, L.L. Berry, Problems and Strategies in Services Marketing, „Journal of Marketing” 1985, vol. 49; L.L. Berry, Relationship Marketing...

${ }_{55}$ W.L. Wilkie, E.S. Moore, op. cit.

56 J. Brady, I. Davis, Marketing's Mid-Life Crisis, „The McKinsey Quarterly” 1993, vol. 2; Coopers \& Lybrand, Marketing on the Crossroads, Coopers \& Lybrand, 1994.

${ }^{57}$ B.P. Shapiro, What the Hell is Market Oriented?, „Harvard Business Review” 1988, November-December.

58 A.K. Kohli, B.J. Jaworski, Market Orientation - The Construct, Research Proposition and Managerial Implications, „Journal of Marketing” 1990, vol. 54.

59 J.C. Narver, S.F. Slater, The Effect of a Market Orientation on Business Profitability, „Journal of Marketing" 1990, vol. 54. 
tynuowany był m.in. przez F. Webstera ${ }^{60}$, G. Daya ${ }^{61}$ czy J. Shetha i R. Sisodię ${ }^{62}$. $\mathrm{Z}$ jednej strony koncentruje się on na opisaniu, czym jest marketing, jakie są jego funkcje $\mathrm{w}$ organizacji, $\mathrm{z}$ drugiej natomiast strony badacze podejmują próbę określania, w jakim stopniu marketing przyczynia się do budowania wartości i jak wiąże się on z sukcesem firmy. Rozważania te wyraźnie koncentrują się na umiejscawianiu marketingu nie jako wyłącznie procesu społecznego, ani nie jako wyłącznie procesu zarządczego. Wskazują one zarówno na kulturotwórczą rolę marketingu w organizacji, jak i działania związane z implementacją. Doprowadza to do wskazywania na marketing jako fundament organizacji uczących się oraz odnosi się do integrującej roli marketingu w sensie zarządczym ${ }^{63}$.

Drugi wyraźny nurt dotyczy określenia możliwości pomiaru działań marketingowych zarówno od strony procesu, jak i efektów. Jest więc kontynuacją prac związanych z określaniem i oceną wartości, jakie dodaje marketing do produk-

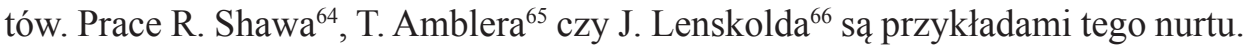
Marketing nie jest już tutaj postrzegany jedynie jako funkcja czy zestaw operacji rynkowych. Ma on raczej wymiar bardziej strategiczny, reprezentuje holistyczne podejście $\mathrm{z}$ nakierowaniem na umiejętności zarządcze oraz finansowe aspekty działań marketingowych. Badacze podejmują próbę integracji dotychczasowych kierunków myślenia. Klient w wielu publikacjach jest już nie tylko elementem zainteresowania organizacji, ale staje się jej partnerem. Menedżerowie i badacze poszukują odpowiedzi na pytanie o wartości, jakie oferują firmy i jakimi mogą konkurować. Wskazuje się na potrzebę procesowego podejścia i spojrzenia na organizację i zachodzące w niej procesy jako na całość.

Nie można oczywiście nie zaważyć także szeregu publikacji oraz praktyki biznesowej odnoszących się do poszczególnych narzędzi i technik marketingu. Dotyczy to szczególnie wykorzystania technologii informatycznej. Szereg publikacji, które poruszają problematykę wykorzystania Internetu ${ }^{67}$,

${ }^{60}$ F.E. Webster, Executing the New Marketing Concept, „Marketing Management” 1994, vol. 3.

${ }^{61}$ G.S. Day, The Capabilities of Market-Driven Organizations, „Journal of Marketing” 1994, vol. 58.

${ }^{62}$ J.N. Sheth, R.S. Sisodia, Does Marketing Need Reform?, ,Journal of Marketing” 2005, vol. 69.

${ }^{63}$ S.F. Slater, J.C. Narver, Market Orientation and the Learning Organization, „Journal of Marketing" 1995, vol. 59.

${ }^{64}$ R. Shaw, Improving Marketing Effectiveness, Economist Newspaper Ltd., London 1998.

${ }_{65}$ T. Ambler, Marketing and the Bottom Line, Prentice Hall, London 2003.

${ }^{66}$ J.D. Lenskold, Marketing ROI - the Path to Campaign, Customer, and Corporate Profitability, McGraw Hill, New York 2003.

${ }^{67}$ Np. D. Chaffey, F. Eblis-Chadwick, K. Johnston, R. Mayer, Internet Marketing - Strategy, Implementation and Practice, Prentice Hall, London 2000; J. Sterne, World Wide Web Marketing, Wiley, New York 1999. 
$\mathrm{CRM}^{68}$ oraz E-Commerce ${ }^{69}$, ukazuje się na początku XXI wieku. Uwzględnia się w nich jednak coraz częściej systemowe podejście, rozważa się ich efektywność i wkład w budowanie wartości dla klienta.

Marketing zmierza więc do zharmonizowanego połączenia sfery powszechnie nazywanej miękką - społeczną, kreatywną, koncepcyjną, strategiczną oraz twardej - zarządczej, ilościowej, operacyjnej, aplikacyjnej. Marketing zaczyna powoli wracać do źródeł i korzystać z dokonań poprzedników. Z jednej strony zarzuty, które przedstawia się dzisiejszemu marketingowi, miały podobny charakter 10 lat temu ${ }^{70}$, a nawet prawie 100 lat temu $^{71}$. $\mathrm{Z}$ drugiej natomiast to już w początkach formowania myśli marketingowej wskazywano na takie elementy, jak rola klienta ${ }^{72}$, proces $^{73}$ i pomiar ${ }^{74}$. Można więc powiedzieć, że szukając tożsamości marketingu warto spojrzeć na jego korzenie i źródła powstania. Obok wielu nurtów można znaleźć tam wyznaczniki jego identyfikacji. Coraz częściej więc marketing definiowany jest ponownie jako proces, z jednoczesną potrzebą określenia wartości, jakie niesie i na jakich się opiera oraz możliwościami pomiaru efektów i działań rynkowych. Zmierza do głębszego wyrażania zrozumienia dla klienta i większego szacunku dla niego. Ustawia się nie w roli wszechwiedzącego dostawcy, ale raczej w roli łącznika klienta z organizacją.

\section{Bibliografia}

Ambler T., Marketing and the Bottom Line, Prentice Hall, London 2003

Ambler T., Kokkinaki F., Puntoni S., Riley D., Assessing Market Performance The Current State of Metrics, Centre for Marketing, London Business School, Working Paper 2001, September

Alderson W., A Marketing View of Competition, „Journal of Marketing” 1937, vol. 1

Alderson W., Marketing Behavior and Executive Action, Richard D. Irwin, Homewood 1957

${ }^{68}$ E. Peelen, Customer Relationship Management, Prentice Hall, New York 2005; H. Wilson, E. Daniel, M. McDonald, Factors for Success in Customer Relationship Management (CRM) Systems, „Journal of Marketing Management” 2002, vol. 18/1.

${ }^{69} \mathrm{~Np}$., D. Chaffey, E-Business and E-Commerce Management, Prentice Hall, Harlow 2006;

B. Gregor, M. Stawiszyński, E-Commerce, Oficyna Wydawnicza Branta, Bydgoszcz-Lódź 2002.

70 J. Brady, I. Davis, op. cit.; Coopers \& Lybrand, op. cit.

${ }^{71}$ E.D. Jones, op. cit.

72 P.F. Drucker, op. cit.; J.B. McKitterick, op. cit.; T. Levitt, op. cit.

${ }^{73}$ W. Alderson, R. Cox, op. cit.

${ }^{74}$ R.A. Feder, How to Measure Marketing Performance, „Harvard Business Review” 1965, May-June. 
Anderson W., Cox R., Towards a Theory of Marketing, „Journal of Marketing” 1948, vol. XIII

Bartels R., Can Marketing Be a Science?, „Journal of Marketing” 1951, vol. 15

Bartels R., Development of Marketing Though - a Brief History, [w:] G. Schwarz, Science in Marketing, J. Wiley \& Sons, New York 1965

Bartels R., Development of Marketing Thought, Homewood, Irwin Press, Chicago, IL 1962

Bartels R., The History of Marketing Thought, Gorsuch Scarisbrick Pub, New York 1988

Bartels R., The Identity Crisis in Marketing, „Journal of Marketing” 1974, October

Bartels R., Sociologists and Marketologists, „Journal of Marketing” 1959, vol. 24

Bartels R., Beckman T.N., Cullman W.A., Davidson W.R., Davis J.H., Doody A.F., Engel J.F., Heskett J.L., Howel R.A., Miner R.B., Morgenroth W.M., Stern L.W., Yocum J.C., A Statement of Marketing Philosophy, „Journal of Marketing" 1965, vol. 29

Berry L.L., Relationship Marketing, [w:] L.L. Berry, L. Schostack, G.D. Upah, Emerging Perspectives of Services Marketing, American Marketing Association, Chicago 1983

Białecki K., Gołębiowski T., W poszukiwaniu tożsamości marketingu-marketing a ekonomia i zarządzanie, [w:] Kontrowersje wokót marketingu w Polsce tożsamość, etyka, przyszłość, red. L. Garbarski, Wyd. Wyższej Szkoły Przedsiębiorczości i Zarządzania im. Leona Koźmińskiego w Warszawie, Warszawa 2004

Brady J., Davis I., Marketing's Mid-Life Crisis, „The McKinsey Quarterly” 1993, vol. 2

Brownlie D., Saren M., The Four Ps of the Marketing Concept: Prescriptive, Polemical, Permanent and Problematical, „European Journal of Marketing” 1991, vol. 26

Bussiere D., Evidence of a Marketing Periodic Literature Within the American Economic Association: 1895-1936, „Journal of Macromarketing” 2000, vol. 20

Celuch K.G., Kasouf C. J., Peruvemba V., The Effects of Perceived Market and Learning Orientation on Assessed Organizational Capabilities, „Industrial Marketing Management" 2000, vol. 31

Chaffey D., E-Business and E-Commerce Management, Prentice Hall, Harlow 2006

Chaffey D., Eblis-Chadwick F., Johnston K., Mayer R., Internet Marketing Strategy, Implementation and Practice, Prentice Hall, London 2000 
Cherington P.T., The Elements of Marketing, Macmillan, New York 1920

Clark F.E., Principles of Marketing, Macmillan, New York 1922

Converse P.D., The Development of the Science of Marketing - An Exploratory

Survey, ,Journal of Marketing” 1945, vol. 10

Converse P.D., The Elements of Marketing, Prentice Hall, New York 1935

Coopers \& Lybrand, Marketing on the Crossroads, Coopers \& Lybrand 1994

Day G.S., The Capabilities of Market-Driven Organizations, ,Journal of Marketing" 1994, vol. 58

Drucker P.F., The Practice of Management, Hopper and Row, New York 1954

Feder R.A., How to Measure Marketing Performance, „Harvard Business Review" 1965, May/June

Fullerton R.A., How Modern is Modern Marketing? Marketing's Evolution and the Myth of the "Production Era”, „Journal of Marketing” 1988, vol. 52

Gregor B., Stawiszyński M., E-Commerce, Oficyna Wydawnicza Branta, Bydgoszcz-Łódź 2002

Gronroos Ch., A Service Quality Model and its Marketing Implications, „European Journal of Marketing" 1988, vol. 18

Gummesson E., The New Marketing - Developing Long-Term Interactive Relationships, „Long Range Planning” 1987, vol. 20/4

Hagerty J.E., Experiences of an Early Marketing Teacher, ,Journal of Marketing” 1936, vol. 1, July

Howard J.A., Marketing Management - Analysis and Planning, Richard D. Irwin, Homewood 1957

Howell Ch., Toward a History of Management Thought, Business and Economic History, vol. 21, Fall 1995

Jonassen C.T., Contributions of Sociology to Marketing, „Journal of Marketing” 1959, October

Jones D.G.B., Monieson D.D., Early Development of the Philosophy of Marketing Thought, „Journal of Marketing” 1990, vol. 54

Jones D.G.B., Shaw E.H., A History of Marketing Thought, [w:] B.A. Weitz, R. Wensley, Handbook of Marketing, Sage Publications, Thousand Oaks 2002 Jones E.D., The Larger Aspects of Private Business, Mill Supplies, vol. 1. 1911 Kerin R.A., In Pursuit of an Ideal - The Editorial and Literary History of the Journal of Marketing, „Journal of Marketing” 1996, vol. 60

Kohli A.K., Jaworski B.J., Market Orientation - The Construct, Research Proposition and Managerial Implications, „Journal of Marketing” 1990, vol. 54 Kotler Ph., Marketing Management - Analysis, Planning and Control, Prentice Hall, Englewood Cliffs, NJ 1967 
Lenskold J.D., Marketing ROI - the Path to Campaign, Customer, and Corporate Profitability, McGraw Hill, New York 2003

Levitt T., Marketing Myopia, „Harvard Business Review” 1960, vol. 38

Marshall A., Principles of Economics (1890), Reprint, Macmillan, London 1927

Maynard H.H., Weidler W.C., Beckman T.N., Principles of Marketing, Ronald Press Company, New York 1927

McCarthy E.J., Basic Marketing - A Managerial Approach, Richard D. Irwin, Homewood 1960

McKitterick J.B., What is Marketing Management Concept, [w:] F.M. Bass, Frontiers of Marketing Thought and Science, American Marketing Association, Chicago 1957

Myers J.G., Massy W.F., Greyser S.A., Marketing Research and Knowledge Development, Prentice Hall, Englewood Cliffs, NJ 1980

Narver J.C., Slater S.F., The Effect of a Market Orientation on Business Profitability, ,Journal of Marketing” 1990, vol. 54

Nystrom P., The Economics of Retailing, vol. 1/2, Ronald Press, New York 1915

Peelen E., Customer Relationship Management, Prentice Hall, New York, 2005

Sagan A., Teoretyczne podstawy marketingu - 50 lat poszukiwań, „Marketing i Rynek" 2000, nr 7

Savitt R., Pre-Aldersonian Antecedents to Macromarketing - Insights from the Textual Literature, „Journal of the Academy of Marketing Science”1990, vol. 18

Say J., A Treatise on the Political Economy: Wells and Lilly, Boston 1821

Shapiro B.P., What the Hell is "Market Oriented'?, „Harvard Business Review” 1988, November-December

Shaw R., Improving Marketing Effectiveness, Economist Newspaper Ltd., London 1998

Shaw A., Some Problems in Market Distribution, „Quarterly Journal of Economics" 1912, vol. 12

Sheth J.N., Sisodia R.S., Does Marketing Need Reform?, „Journal of Marketing” 2005, vol. 69

Slater S.F., Narver J.C., Market Orientation and the Learning Organization, „Journal of Marketing” 1995, vol. 59

Smith A., A Inquiry into the Nature and Causes of the Wealth of Nations (1776), Reprint, W. Strahan and T. Cadell, London 1904

Sterne J., World Wide Web Marketing, Wiley, New York 1999

Vargo S.L., Lusch R.F., Evolving to a New Dominant Logic for Marketing, ,Journal of Marketing" 2004, vol. 68

Webster F.E., Executing the New Marketing Concept, „Marketing Management” 1994, vol. 3 
Webster F.E., Marketing Management in Changing Times, „Marketing Management" 2002, January/February

Wilson H., Daniel E., McDonald M., Factors for Success in Customer Relationship Management (CRM) Systems, „Journal of Marketing Management” 2002, vol. 18/1

Zeithaml V.A., Parasuraman A., Berry L.L., Problems and Strategies in Services Marketing, „Journal of Marketing” 1985, vol. 49http://cepa.newschool.edu/ het/schools/historic.htm

Żabiński L., O niektórych argumentach krytyki marketingu jako dyscypliny nauki - polemicznie, [w:], Kontrowersje wokół marketingu w Polsce - tożsamość, etyka, przyszłość, red. L. Garbarski, Wyd. Wyższej Szkoły Przedsiębiorczości i Zarządzania im. Leona Koźmińskiego w Warszawie, Warszawa 2004 